\title{
The Theatre of Cruelty: Dehumanization, Objectification \& Abu Ghraib
}

\section{by Christiana Spens}

\section{(cc) $\mathrm{BY}$}

This work is licensed under a Creative Commons Attribution 3.0 License.

\section{Introduction}

A clumsy pyramid of kneeling men, naked apart from the hoods over their heads, with a smiling, fairheaded woman and a grinning man with a moustache, wearing green cleaning gloves; a slight woman with a blank expression and a man on the floor, on a limp leash; a hooded, robed figure, standing on a box with his arms outstretched and a pose similar to the crucifixion, with sinister wires behind him, and otherwise blank surroundings. A row of more hooded, naked men, forced to do sexual acts as a female prison guard (Lynndie England), tanned and wearing various shades of khaki, grins and does a thumbs up sign, pointing at him, her cigarette tilted and her expression not altogether different from Bonnie in Bonnie and Clyde. A man in uniform and a black beanie hat, sitting on an Iraqi prisoner. Another pyramid of naked detainees, with a man and women behind them, smiling arm in arm, as if they are standing by a caught wild boar or large fish, or a well-organised barbeque. The moustached man (Charles Graner), again smiling and giving a thumbs up sign, this time over a corpse, whose bloody eyes have been bandaged. A naked prisoner covering his ears, as several dogs bark at him, and soldiers watch on. Another prisoner chained to a bed-frame, with some underpants covering his face. These infamous scenes, shown in the Abu Ghraib photographs, shocked many people, and the perpetrators of the torture depicted were condemned by the relevant authorities. They transformed from clandestine mementos of hidden violence to records of an international scandal and evidence of serious crime. Their meaning changed depending on who saw them, how they were interpreted, what reactions they provoked, and the rulings of the courts regarding the people involved. They went from being private victory shots, to an international public relations disaster, to evidence of breaking of the Geneva Convention.

This paper will examine the way in which the meaning of the Abu Ghraib photographs changed, and why, comparing the phenomenon to similar historical precedents such as the lynching photographs of the early twentieth century USA, and the violent pornography that emerged from Bosnia in the early 1990s. It will also discuss similar cases from further back in history, such as the witch trials of the 1660s and Guy Fawkes' punishment following the alleged Gunpowder plot, which occurred before the advent of photography but displayed similar characteristics in terms of the use of spectacular public violence, and its changing meaning in years following. The paper will take a particularly aesthetic approach to this analysis, and in so doing place the photographs in the context of a historical tendency of symbolic and visually aware violence being used to dehumanise and 'other' politically threatening groups. It is hoped that this will serve as a foundation to better understand how dehumanisation works, and how visual and dramatic techniques are used in a political context.

Specifically, the paper aims to uncover a pattern between the Abu Ghraib scandal, and these historical precedents, in order to better understand the flexible meaning of the photographs, and what they say about society's relationship with public violence as a form of communication. (Jabri, 1996) It will argue that the 


\section{Journal of Terrorism Research}

Abu Ghraib scandal is a concise, modern example of public, symbolic violence being used as a mechanism for 'othering', as well as exposing how changeable that 'othering' can be. In other words, violence used to 'other' through objectification and dehumanisation can have the opposite effect if there is sufficient public engagement with alternative interpretations. The 'villain' narrative, that is present in all cases referred to (and especially in the three the paper will examine more closely), is not fixed: the 'villain' role can be passed from punished to perpetrator easily, if the will of the public, or audience is there.

\section{Abu Ghraib as 'Outsider Art': A New Way of Thinking about Political Violence}

The set of photographs from Abu Ghraib are reminiscent of many instances of spectacular, symbolic violence - from private to public, from recent to historical cases, and from fictional to non-fictional violence. These photographs look like stills from a play of the Theatre of Cruelty - a drama in the vein of Artaud (1938) or the Marquis de Sade (Philips, 2005) - with its narcissism, sadism and brutality. The photographs feature hoods that could have been borrowed from mediaeval torture chambers, or witch trials of the 1600s in Europe or the USA. The use of triangular composition appears borrowed from the fine art of the Renaissance, and the pose of the 'hooded man' by paintings of the crucifixion. Black gowns look like they were picked out of the wardrobe from the Scream films of the 1990s, or a Halloween parade. The Abu Ghraib set, if not so politically loaded, could easily be labelled as a kind of Art Brut, or 'outsider art' (Dubuffet, 1967), in its seemingly unconscious use of performance and art, beyond the realms and rules of the art world but disconcertingly reminiscent of techniques and motifs used by painters and performance artists the world over. As it is, commentators have understandably been careful not to be seen to trivialise the photographs of torture by pointing out these historical and aesthetic precedents and references. They are not works of art, but war crimes. This paper suggests that the two terms are not mutually exclusive. Rather, the use of performance, artistic techniques and communicative violence has long been present in public punishment and other violence, in political violence especially, and with good reason. (Carr, 2011)

Spectacular, symbolic violence can be extremely effective in emotionally manipulating whoever sees the violence, and whoever is victim of it. The existence of a camera or a physical audience heightens humiliation of victims, and the sense of horror in audience makes deterrence effective. Significantly, too, the use of public violence can be a tool of social division - of objectifying, dehumanising and 'othering' an individual or a whole community represented by that individual. As this paper will explain, history is full of examples of this behaviour. While it can only introduce such ideas, and the notion of a 'history of the art of political violence, it is hoped that this initial discussion will put in place some foundation for further study that seeks to understand political violence through a thorough interrogation of its aesthetic and dramatic elements.

\section{Literature Review}

While there has been much discussion of the Abu Ghraib photographs, very little has touched on its historical precedents, or the aesthetic elements of the photographs and torture depicted. Emphasis has, necessarily, been on the role of torture and related moral implications (Danchev, 2008; Todorov, 2009); and the political implications, particularly the way in which the photographs exposed torture and hypocrisy of the US government and military (Danner, 2004), implications of the blow to the reputation of the US (Hersh, 2004), especially the reaction from the Muslim community, and the international community more generally. There has been discussion of what the leaking and distribution of these images globally means for government attempts at (military) censorship, issues of freedom of speech versus national security, and the 


\section{Journal of Terrorism Research}

effect of the Internet on public understanding of warfare and the efficiency and effectiveness of revolutionary propaganda. (Bolt, 2012).

This paper proposes, however, that the full political implications of these photographs cannot be understood without examining more specifically the aesthetic and historical context of the photographs and the behaviour - the use of spectacular violence for dehumanisation and 'othering' - that they represent. Furthermore, the way in which political meaning and message can change depending on 're-framing' of images and wider narratives cannot be properly understood without careful consideration of how these changes of perception happen, and have happened historically. How the public relate to images such as those taken in Abu Ghraib prison, and how images work to alienate or engage or provoke people can be better understood by undertaking a historical visual analysis that considers the Abu Ghraib pictures in the context of similar brutal and symbolic violence, with a specific focus on their visual connotations.

Of the recent books on this topic, there are only brief comparisons made with historical examples but no full report considering each of those groups. For example, in Lynching Photographs (Apel \& Smith, 2007), the authors suggest a link to the Abu Ghraib photographs, but do not go into very much depth about this connection; rather it is a suggestion of the relevance of the lynching photographs to the modern world, and a suggestion of further research, which this paper will hopefully contribute to. In Mother, Monster, Whore, (Sjoberg \& Gentry, 2007) the authors go into great depth about the way in which the Abu Ghraib narrative was gendered, and the connections to pornography, which were very helpful in this study. However that book, in focusing on gender issues, did not go into as much depth with comparative racial issues and especially the wider context of images of war and punishment, so this paper aims to expand that research in a way that should complement the existing work by Sjoberg and Gentry.

Four books are particularly insightful with regard to violent imagery and the media: Cloning Terror by W. T. J. Mitchell (2011), The Violent Image by Neville Bolt (2012), Frames of War by Judith Butler (2009), and The Terrorism Spectacle by Steven Livingston (1994). Between them, they discuss violent imagery and the media with reference to art theory and new biotechnology issues (Mitchell), the study of revolution, insurgency and modern technologies (Bolt, 2012), feminism and wider power dynamics (Butler, 2007), and a critical terrorism studies approach (Livingston, 1994). Each of these titles are insightful and useful in understanding the Abu Ghraib pictures, but as yet there is no work combining these insights, and especially with regard to Abu Ghraib. Given that these images are so iconic in the context of the ongoing War on Terror especially, and their relevance to current debates about issues of torture, censorship and pornography, it seems necessary to analyse them specifically, and with reference to the existing scholarship on terrorism and the media. In some respects, furthermore, analysis of the Abu Ghraib pictures signals a change in the way that violent imagery is understood. A fresh study of these pictures should enrich existing study of the wider subject of terrorism and the media, and expand on points made by Sjoberg, Gentry, Apel, Smith, MacKinnon and Butler, on the connections between images from war, pornography and lynching.

\section{Methodology}

This paper will analyse the Abu Ghraib photographs with a historical visual analysis, which selects primary cases for comparison (lynching photographs from the American South, early twentieth century, and photographs depicting torture and sexual abuse used in the Bosnian conflict of the early 1990s), as well as referencing a wider historical context, when useful connections and historical references can be used and revealed. The paper will argue that in each of these cases, whether clandestine or not, whether directed at a 


\section{Journal of Terrorism Research}

small or global audience, the performance aspect is a tool to objectify and dehumanise the 'other' for political purposes. The Abu Ghraib photographs are part of a long history of performed, aesthetic violence whose central aim is dehumanisation through humiliation and torture.

\section{Historical and Contemporary Context}

Violence that is performed and pictured is nothing new: "The iconography of suffering has a long pedigree," as Susan Sontag writes. $(2003,36)$ It is a normal element of torture past and present, and until quite recently, it was a normal part of most punishment by the state, especially capital punishment such as public hangings. Well-known historical examples include the witch trials of the 1600s in Europe (Maxwell-Stuart, 2003, 2005, 2011) and the USA (Hill, 2000), (see Appendix L for illustration); the punishment of Guy Fawkes after his alleged involvement in the Gunpowder Plot in London (Fraser, 2002; Haynes, 2005; Sharpe, 2005), and the execution of the French aristocracy (among others) during the French Revolution. Although photographs were not taken of these cases, given that photography had not been invented yet, there are nevertheless valuable visual representations of these scenes that were produced contemporarily and in hindsight, and are a fascinating insight into the way that the perception of an event can change through visual representation and interpretation, or 'reframing' (Butler, 2009).

Since the Abu Ghraib scandal, similarly brutal footage has emerged from the Syrian conflict, films of torture an executions associated with the War on Terror (by Al Qaeda), in Afghanistan and Iraq, and associated with the Israel / Palestine conflict. Images of US Marines burning the bodies of 'enemy combatants' emerged in January 2014, (Ackermann, 2014) initially dubbed 'Abu Ghraib 2.0' ('Abu Ghraib 2.0? Horrifying images of US Marines burning Iraqis prompt military investigation,' RT.com 2014) The murder of Lee Rigby in London, in 2012, can also be compared with the Abu Ghraib pictures in the sense that both situations exemplified issues concerning the distribution of politically sensitive images of brutal violence using New Media, in the context of the War on Terror, and could be considered part of the so-called 'war of images' (Bolt, 2012; Mitchell, 2011). While the murder of Lee Rigby was intended to be shown to as wide an audience as possible, however, the Abu Ghraib images were originally intended to be kept secret.

While this paper will look at only the historical (primary) cases as follows, it is worth pointing out that the Abu Ghraib scandal, even in the past couple decades, has not been exceptional in terms of brutality, notoriety or (arguably, for it is very hard to quantify) dramatic political effect. Rather, the Abu Ghraib photographs are a good example of a behaviour, or type of performed violence, that has been repeated throughout history and continues to be used for dehumanisation.

\section{Primary Cases}

This paper, given limited space and for the sake of analytical clarity, will focus on the relatively recent examples in which photography was used: the lynching of black people in the Southern states of the US in the early twentieth century (see Appendix D - G), and the Abu Graib scandal of 2003 - 2004 (Appendix A - C). Reference will be made to other examples already mentioned, and to the torture, sexual abuse and murder of Muslims in the Bosnian conflict of the early 1990s, scenes of which were often photographed or recorded, and that material used in psychological warfare and propaganda also. Given difficulty in accessing the Bosnian material, however, these photographs will be referenced using secondary accounts of the photographs by Catherine MacKinnon (2007), while analysis of the lynching photographs and Abu Ghraib 
photographs will use primary sources (presented in appendixes at the end of the paper).

Of the images taken in Abu Ghraib prison (as described in the introduction), this paper will examine specifically what it will term (a) The Hooded Man, (b) Pyramid of Bodies and (c) Soldier with Prisoner on Leash (each of which is reproduced in the Appendix). These selected images have been chosen for analysis as they are iconic and have been widely reproduced, in the mainstream media, pornography, and in fine art. They have come to visually represent (often subversively) the narrative of the War on Terror and specifically America's role in it. (Mitchell, 2011, 112) The particular images have been chosen because they represent the whole group well, in displaying between them the main characteristics of the group: the sexual pornographic element, as evidenced in the (b) Pyramid of Bodies photograph and (c) Soldier with Prisoner on Leash, and the torture element, clearly illustrated in the (a) Hooded Man photograph.

Of the lynching photographs available, the paper will specifically look at those pictured in Appendix D - K, showing the lynchings of Jesse Washington, Rubin Stacy, John Heith, Henry Smith and Jim Miller, because as a group they provide a good overview of typical lynching scenes, across a number of decades and several states (including Texas, Arizona, Florida and Oklahoma). The lynching of Jesse Washington (D) was included as it was a particularly infamous event (and photograph) and was instrumental in the Civil Rights Movement, and iconic of lynching photographs generally. (Apel \& Smith, 2007)

\section{Analysis}

Through a visual historical analysis of the Abu Ghraib pictures (Appendix A - C) as well as the lynching photographs (Appendix D - K) and referring to the images and events mentioned in the historical context section (including Appendix L), which enabled cross-referencing historically and visually, several interesting motifs emerged that were present across cases:

- The use of rope, as a noose and / or leash (all except A (which uses wires however), and C)

- $\quad$ Tied hands and legs (all)

- $\quad$ Bodies raised above the ground (all except B)

- $\quad$ Relaxed, smiling people watching in the background. Body language included folded arms, leaning on trees, arms on hips, smiling, and relaxed posture. (All except A and J)

- Bodies transformed or presented as barely 'human' or recognisable, whether burnt beyond recognition, or covered with hoods. Also including the body, whether through burning, torture or stress positions, in abnormal positions. (All to some extent, but especially A, B, C, D)

- $\quad$ Triangular composition (A, C, E, F, G, H, I, J, K)

- Victim being made to look like an animal (overtly: B, and J, in being in a stable with animals)

- The use of hoods in the Abu Ghraib pictures $(\mathrm{A}-\mathrm{C})$ is similar to those associated with witches, and other mediaeval torture, and also those worn by the Ku Klux Klan.

- The use of burning in the lynching of Jesse Washington (D) echoes the images of US Marines allegedly burning Iraqi detainees (RT.com, 2014)

- $\quad$ All photos, to some extent, recall traditional hunting 'victory shots', where animals and fish are laid on the ground or held from a string when they are caught, with smiling 'victors' standing around them.

- Racial differences between the victim and those watching the lynching or torture (victim is usually 
black or Asian, spectators are generally white)

- Sexual elements: victims in Appendix A - K are all men, and are often watched by men and women, including young girls (E); these men are often naked or partially dressed (A, B, C, D). (Context point: castration and / or sexual abuse often happened as well as torture and death.)

- All photographs, especially (A and D - K) were reminiscent of the witch trials / burning images, one of which is reproduced in Appendix L.

From these motifs, the analysis revealed several dominant themes that contributed to the overall effect of dehumanization:

- Distortion of physical sexuality (inc. emasculation / castration)

- Destruction and distortion of the body (including skin)

- Association with animals

- Humiliation by staging the torture (body raised above, as on a stage) with an audience, and / or photographing that spectacle

These themes were all tied into a common effect of dehumanisation, of the individual and the group that individual was seen to represent. In other words, the photographs and the acts themselves (depicted in the image), worked to dehumanise in two key ways: (1) through actual destruction of the human body, and (2) through symbolic humiliation and subordination of the person, i.e. by raising the body on a stage or through hanging, through sexual abuse, and by associating the person with animals. In this respect, photography of performance is a means of contributing to (2) the symbolic subordination, and (2) communicating to others (perhaps as a deterrent or symbol of superiority on the part of the perpetrator) the physical and symbolic destruction of the person.

\section{Discussion}

To understand how the methods employed in the Abu Ghraib and lynching photographs work, the paper will consider ideas by Sontag, MacKinnon, Apel and Smith regarding the power dynamics of the torture and abuse, as well as the specific function of performance and photography in dehumanisation. Then it will discuss why this approach is taken in both cases, as well as others briefly mentioned (such as the with burnings, capital punishment, and recent symbolic and performed violence in Syria, London, and elsewhere). What explains the tendency towards performed, symbolic violence? Lastly, the paper will point out the way in which narratives of dehumanisation have historically backfired, and how this happens, to give further insight into the meaning of the Abu Ghraib photographs and the (changing) narrative they illustrate.

\section{The Power Dynamics of Performed Torture}

At the centre of the practice and photography of lynching, which asserted white superiority, there was usually a sexual element. The men lynched in these photographs were often accused of sexual harassment or rape of white women, also the evidence of those crimes was usually unproven. Since inter-racial sexual relations were prohibited, often the term 'rape' was also used to condemn consensual sex between a black person and a white person, and sexual harassment a term to cover up attraction. Sexual anxiety was at the root of race relations more generally, given the stereotyping of black men as sexually virile and aggressive, and intimidating to white men (and their women, since women were seen as property). (Apel \& Smith, 2007, 8) 


\section{Journal of Terrorism Research}

The public lynching of black men who had, for whatever reason, appeared to threaten the white male possession of their white women, was intended to reassert those men's superiority, and to deter other black men from intimidating them, or using their sexual and / or physical power against them, in the future. It was also a way to deter white women, and girls, from engaging with black men. One photo of a lynching is described as "Remarkable for the large number of girls standing about and ogling an abject corpse..." (Apel \& Smith, 2007, 55) One can argue that these girls, in particular, were being socialised to think themselves "superiors of grown black men" (Apel \& Smith, 2007, 56) as well as warned about what might happen if they were ever to engage with such a man. White male supremacism took a 'divide and conquer' approach to the subordination of blacks and women.

Lynching was a tactic used to achieve this end of white male power. Destruction of the (black) body, and symbolic degradation of the individual and the group they symbolise, were the two keys ways that dehumanisation was achieved in the cases of Abu Ghraib also. (Gentry \& Sjoberg, 2007) In both cases, the symbolic, brutal violence functioned to subordinate the victims to the point where they did not appear human, and least of all powerful humans. (Shapiro, 2003)

One of the key ways that symbolic degradation was achieved was through sexual abuse or castration (in the lynchings) (Apel \& Smith, 2007). Sexual abuse is a means of humiliation, which is linked to dehumanisation: the victim is 'broken' and made to feel not human, and anyone watching is shown an individual in a state where he or she is so subordinated or objectified as to seem not completely 'human'. This effect can be heightened, according to MacKinnon (2007), Dworkin (1981) and Williams (2004) by recording that sexual abuse through photography, which heightens the sense of humiliation.

Sexual abuse can also be a weapon in general subordination, and specific racial subordination; sexual humiliation is a way of degrading an ethnic group as well as an individual, if that individual is presented as represented his or her ethnic group. MacKinnon writes specifically about the use of pornography in wartime as a means of waging superiority over women as a tactic in the suppression of a particular ethnic group. In Are Women Human? (2007) MacKinnon discusses the filming of sexual abuse of Bosnian women by Serbian military, and therefore the use of actual genocide and rape in the production of pornography. She recounts how some rapes were aired on the evening news in Banja Luke, a Serb-occupied city in Bosnia-Herzegovina. (MacKinnon, 2007, 163) "Many men watched her raped in person; thousands more watched her raped on television." (MacKinnon, 2007, 163) Snuff films, involving rape, were distributed in a more clandestine manner, but nevertheless likely received a wide audience. "Many tortures in the camps are organised as sexual spectacles, ritualised acts of sadism in which inflicting extreme pain and death are sexual acts, performed and watched for sexual enjoyment." (MacKinnon, 2007, 166-167)

The reason behind the emphasis on sexual abuse in this conflict was that it was a tactic to undermine a whole race. By abusing the Muslim women, the Serbian military were hurting the whole community - not simply in the basic way that hurting people's family and friends would ensure, but also in the sense that they were taking ownership of those women as if they were possessions or land. An extreme consequence of this behaviour was the forced impregnation of thousands of Bosnian women; this was a way of the Serbian military seizing their bodies and reproductive capabilities, and the next generation, as their property. As MacKinnon puts it: "In this system, violating other men's women is planting a flag; it is a way some men say to other men, "What was yours is now mine."'(MacKinnon, 2007, 171)

That men were being sexually assaulted in the Abu Ghraib photographs (and assaulted by women as well as men) is an interesting development of the tendency that MacKinnon discusses. The manner in which 


\section{Journal of Terrorism Research}

the performed abuse objectifies the individuals involved, and reduces them to something to be taken or destroyed (much as land or an animal caught in a hunt) is similar in both instances. As Gentry and Sjoberg point out however, the fact that the victims are male and the perpetrators female is significant in the Abu Ghraib case because the gender roles of each are used to send a message that, in a 'War of Masculinities', America wins over Iraq. (Gentry \& Sjoberg, 2007, 206). "While the United States likely did not plan the publicity of the Abu Ghraib prison scandal as a part of the gendered narrative of state relations, emphasising the women whose participation serves an important function as a victory narrative for American masculinities. After all, 'nothing feminizes masculinity like being beat by a girl, as the old playground adage explains. The images of the prisoner abuse at Abu Ghraib silently tell a story of the ultimate humiliation of Iraqi masculinity because Iraqi men were deprived of their manliness by American women." (Sjoberg, 2007; Gentry \& Sjoberg, 2007, 2006-7). The apparent femininity of the perpetrators, then, is used as a weapon to further humiliate the victims, and to emasculate as well as dehumanise them.

\section{Photography and Performance of Abuse: Why?}

The abuse (and photography of it) during the Bosnian conflict, as interpreted by MacKinnon, has similarities with the Abu Ghraib and lynching cases in terms of racial as well as sexual dynamics, and reference to it suggests the general way that sexual abuse and photography can be used to subordinate not only individuals and states during wartime, but also ethnic groups (whether in wartime or not). (Moeller, 1989) It also suggests the way that photography itself can be a tool of dehumanisation, revealing why photographs were taken of the Abu Ghraib abuse and lynching. While MacKinnon's interpretation is a subjective one, it seems plausible that her insights are correct when considered alongside this paper's findings that visual motifs were important for symbolic dehumanisation, and that performance was key in humiliation. Photography of that performance seems a logical way to heighten that dehumanisation and humiliation, especially given Sontag's take on the function of photography: "Photographs objectify: they turn an event or a person into something that can be possessed. And photographs are a species of alchemy, for all that they are prized as a transparent account of reality." (Sontag, 2003, 72) Whether sexually explicit and / or pornographic, or not, photography can be used as a way to objectify individuals depicted, to varying degrees. (Chambers, 2008) Why, however, is torture and death performed (and visually loaded) at all, let alone photographed?

Juergensmeyer discusses the idea of a violent act as a performance in Terror in the Mind of God: The Global Rise of Religious Violence, and argues that the root of this behaviour is in religious rituals. Political violence (often torture) that uses symbolic performance does so in a way that is parasitical on religious ceremony (Juergensmeyer, 2000, 119). This performative aspect of the violence is not all strategic, he says: it is a type of public ritual, developed and conscious of religious ceremony. Themes of martyrdom, resurrection, transcendence, and judgment, are common themes in most major religions, especially Christianity, Judaism and Islam. Juergensmeyer argues that being socialized into religion, and a religious way of thinking - having these themes and ideas indoctrinated in one's thoughts, normalizes public ritual, martyrdom, and symbolic gestures about subjects of life, death and resurrection. As Sontag agrees:

"The spectacular is very much part of the religious narratives by which suffering, throughout most of

Western history, has been understood. To feel the pulse of Christian iconography in certain wartime or disaster-prone photographs is not a sentimental projection..." (Sontag, 2003, 71)

The narratives, in other words, are already in place, in religion and in art that is religious, and political dramas and conflicts can be explained through them. Because so many people are also aware of these rituals, 


\section{Journal of Terrorism Research}

and deeply entrenched ideas and themes, the 'audience' is likely to be receptive to them, and emotionally react to the violence. This sort of violence exploits this inherent human trait, and tendency to engage in ritual and spectacle, rather than linking it directly and exclusively to religious ritual. Themes of resurrection, martyrdom and sacrifice have played a part in many societies and philosophies, as well as the major religions that Juergensmeyer is concerned with.

Douglas's Purity and Danger (1966) links these various rituals and performances (as well as other forms of social behaviour, including non-performative violence) to a fundamental desire for purging and purification, which exists beyond religion and modern thought, and which she argues is a common theme in all human societies. The link between violence and ritual is intriguing, and even if it cannot be explained by religious ritual per se, it can be explained as a fundamental trait of human nature. If that is so, then spectacular violence engages with this tendency because people react to ritual, just as religious organizations and artists also exploit this human trait to communicate their points and desires. The main point is that all of these forms are communicative.

The Abu Ghraib and lynching photographs are examples of the way in which violence can be used to communicate ideas. In these cases, the ideas being communicated are related to perception of power: in the case of the lynching photographs, the idea was that white men are superior to black men (and all women) and that any threat to that superiority will be punished. In the case of Abu Ghraib, the original message is that the detainees are completely subservient to the perpetrators of the violence, and that the perpetrators have achieved some sort of victory by abusing them. In both cases, there is an implicit communication of the idea that those lynched or tortured are less than human, and 'other'. The irony of both the Abu Ghraib and lynching photographs, however, is that although within the originally intended audience of the photos, the 'performance' worked as intended, because the photos were leaked to the press and received by a wider (unintended) audience, the perpetrators were 'othered' more than the victims. Even the USA was 'othered' for seeming to allow torture to happen, rather than the Muslim detainees.

Meaning and effect is dependent on the framing of and interpretation of those images and ideas, as Judith Butler explains in Frames of War. (2009, 10 - 11) Butler points out that the Abu Ghraib pictures broke out of their original frames, from private to public, and that this re-framing is hugely significant politically, because it enables people to see 'enemy' lives as human and grievable, just as we saw in the development of the presentation of lynching photographs, from images that celebrated and compounded racism, and dehumanised the victims, to images that were used as evidence of wrongdoing and a means of shaming the communities who perpetrated those crimes, which became part of the Civil Rights movement. The photographs were key to raising awareness and condemnation of racism, because they were reframed. (Apel \& Smith, 2007, 78) This possibility of re-framing is central to the new trends apparent in the use of the Internet for the communication of images that would previously have been censored, hidden, and kept relatively private - or "framed" in the conventional way that Butler talks of. By reframing an image or narrative, 'othering' can be challenged and changed. The villain role is therefore flexible and transferable.

What can be learnt from Abu Ghraib, as well as the lynching photos and other cases briefly mentioned, is that 'othering' a group or individual through performed, brutal violence achieves no static end; it changes as perception and audience do, and often the perpetrators are eventually seen as criminal and immoral, rather than victorious, and the victims, however humiliated, nevertheless individuals worthy of compassion, rather than merely symbols. Dehumanisation does not take away a person's humanity indefinitely, even if it takes away his or her body. It takes away other people's perception of that humanity, however, in therein lies the 


\section{Journal of Terrorism Research}

political power of performed violence against 'others', and its persistence as a public relations tool in warfare as well as times of civil unrest and division.

About the author: Christiana Spens read Philosophy at Cambridge, before the M.Litt Terrorism Studies, University of St. Andrews. She is now a PhD Candidate in International Relations at St. Andrews, having been awarded the Dr.Handa PhD Scholarship, 2013-2016. She is an editor (interviews and book reviews) for the New Strategist, and writes regularly for Studio International.

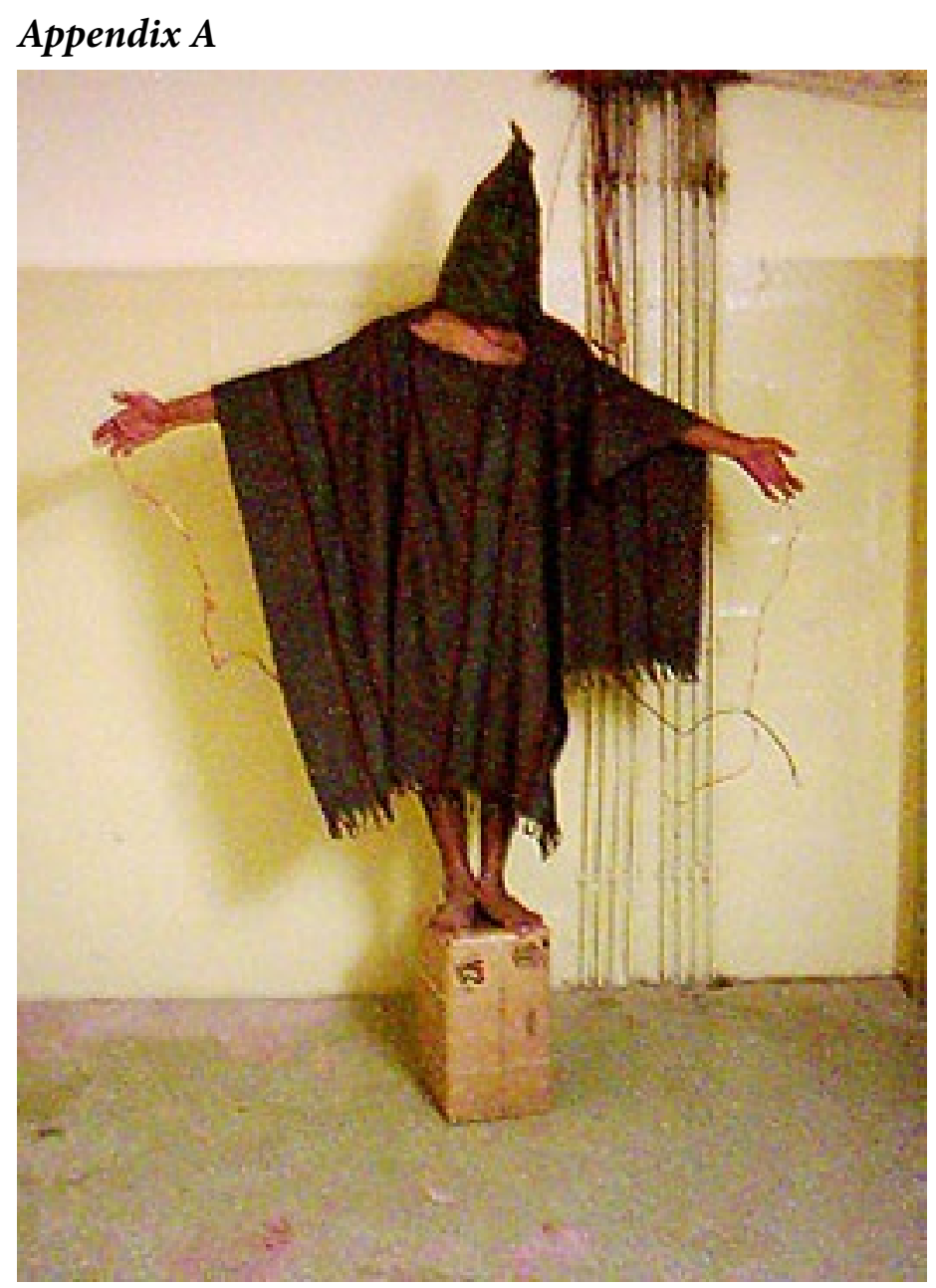

US Military Personnel (2003) "Hooded Man.

This image is in the public domain, as justified by Wikimedia Commons: "This image is in the public domain because it is ineligible for copyright. This applies worldwide. Pictures taken by U. S. military personnel as part of that person's official duties are ineligible for copyright. The photographers of the Abu Ghraib prisoner abuse photos have asserted this was the case under oath." Accessed on 17 / 07 / 13 at: http://en.wikipedia.org/ wiki/File:AbuGhraibAbuse-standing-on-box.jpg 


\section{Journal of Terrorism Research}

\section{Appendix B}

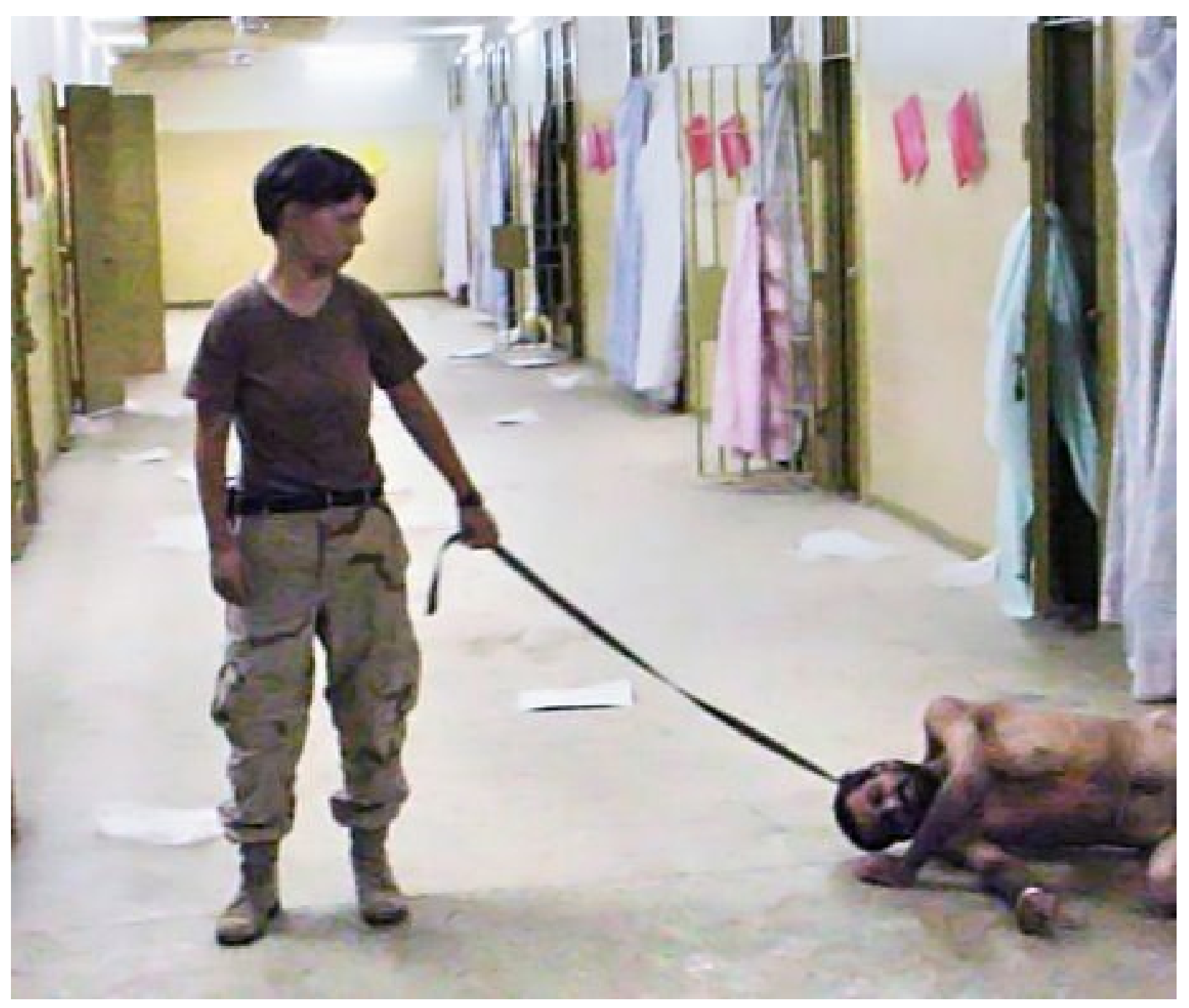

US Military Personnel (2003) "Soldier with Abu Ghraib prisoner on leash"

Ibid. Accessed on 17 / 07 / 13 at: http://en.wikipedia.org/wiki/File:Abu-ghraib-leash.jpg 
The Centre for the Study of Terrorism and Political Violence

\section{Journal of Terrorism Research}

\section{Appendix C}

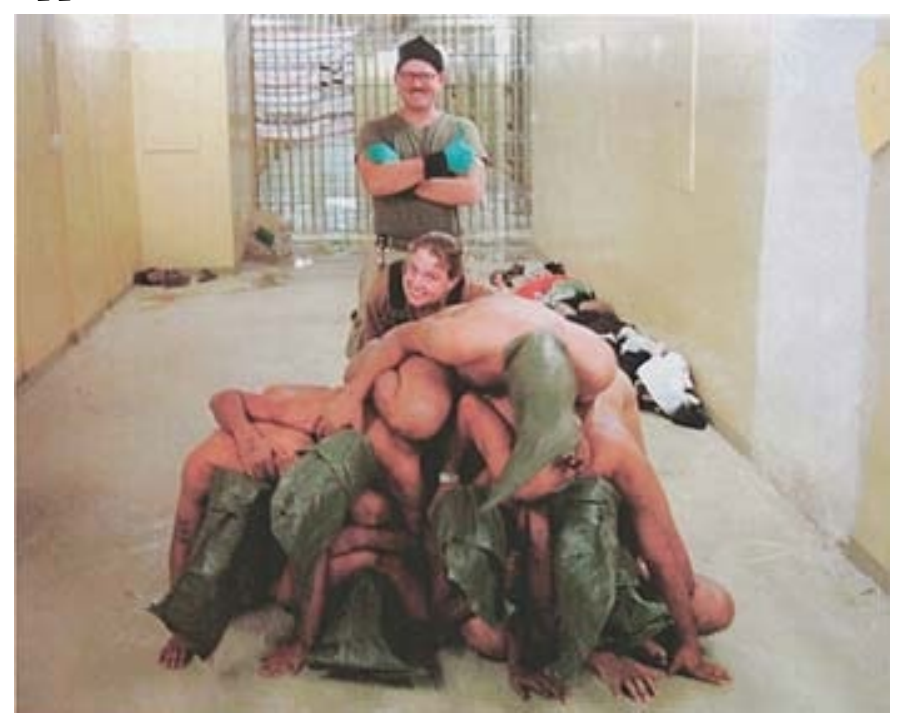

US Military Personnel (2003) "Pyramid of Bodies"

Ibid. Accessed on 17 / 07 / 13 at: http://www.newyorker.com/archive/2004/05/03/slideshow 040503\#slide=2 


\section{Journal of Terrorism Research}

\section{Appendix D}

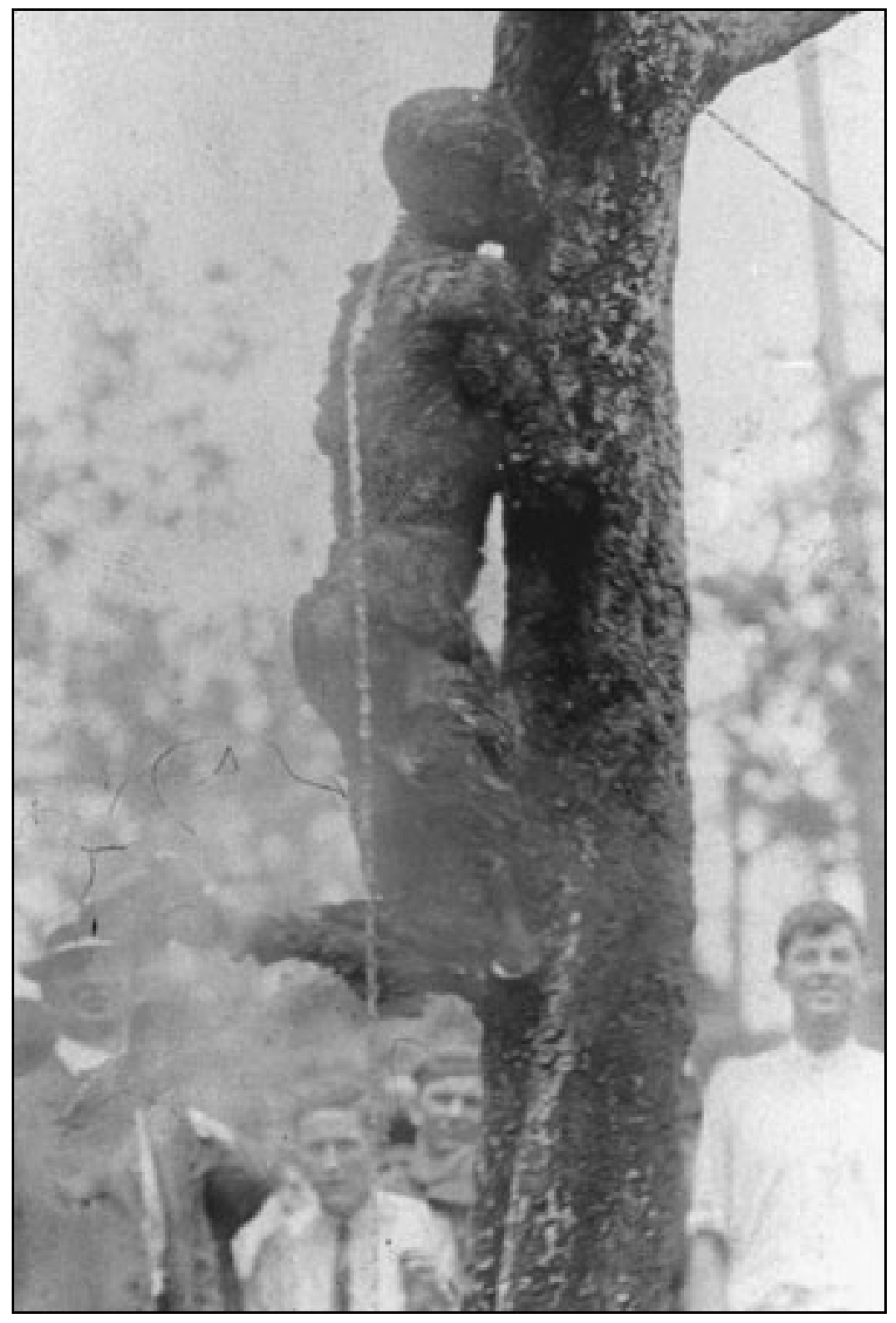

The lynching of Jesse Washington in progress, by Fred Gildersleeve, May 15, 1916. Published by the NAACP after their investigation of the lynching in The Crisis Vol. 12, supplement to No. 3. Accessed on March 25, 2014 at: http://www.npr.org/templates/story/story.php?storyId=5401868 


\section{Journal of Terrorism Research}

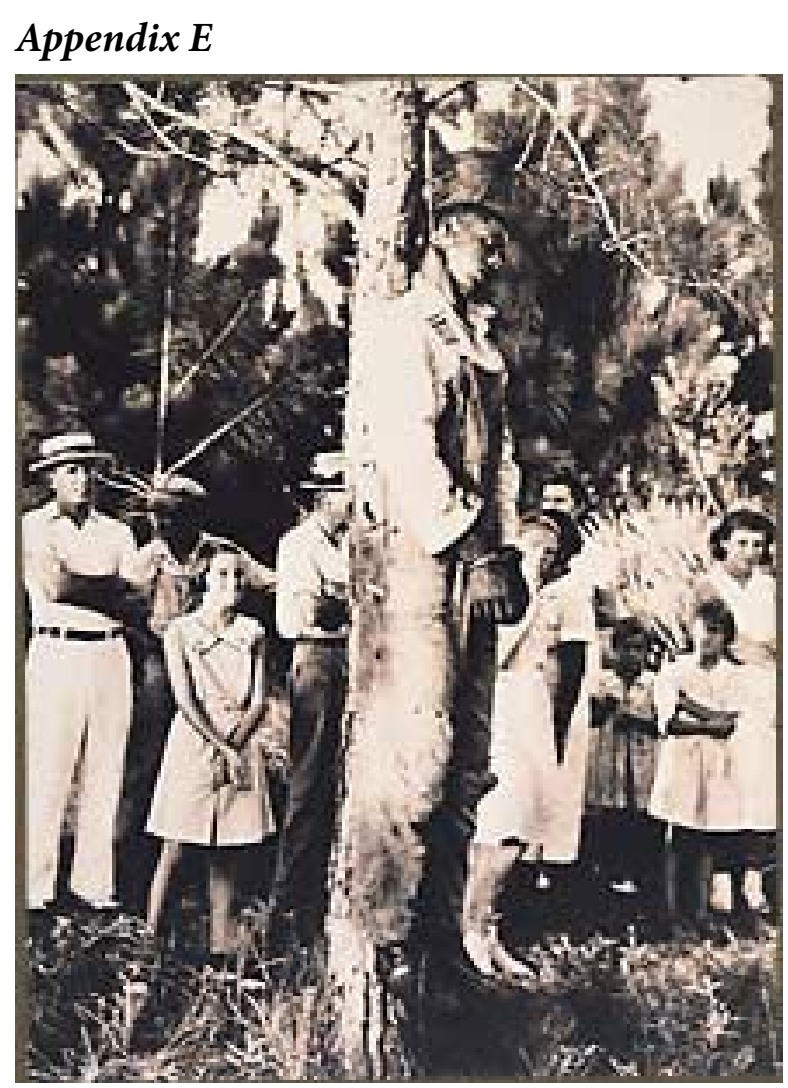

The lynching of Rubin Stacy, July 19, 1935, Fort Lauderdale, Florida. Published in Strange Fruit: Biography of a Song by D. Margolick, 2001. Accessed on March 25, 2014 at: http://www.blackyouthproject.com/2011/02/ the-rubin-stacy-story-a-meditation-on-lynching-in-a-post-racial-america/

\section{Appendix $F$}

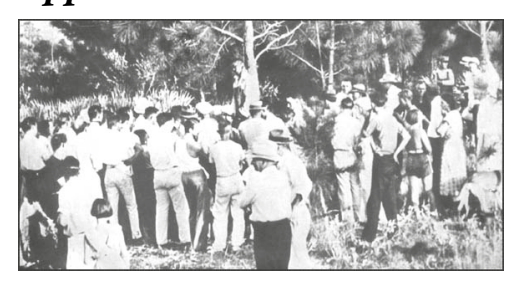

The lynching of Rubin Stacy, July 19, 1935, Fort Lauderdale, Florida. Published in Strange Fruit: Biography of a Song by D. Margolick, 2001. Accessed on March 25, 2014 at: http://www.blackyouthproject.com/2011/02/ the-rubin-stacy-story-a-meditation-on-lynching-in-a-post-racial-america/ 


\section{Journal of Terrorism Research}

\section{Appendix G}

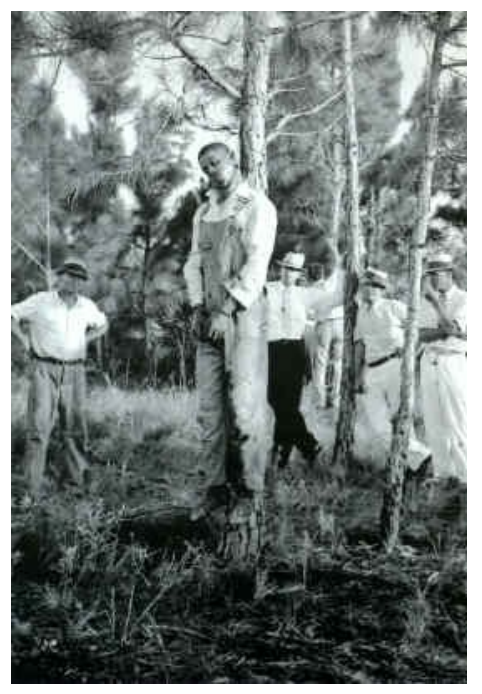

The lynching of Rubin Stacy, July 19, 1935, Fort Lauderdale, Florida. Published in Strange Fruit: Biography of a Song by D. Margolick, 2001. Accessed on March 25, 2014 at: http://www.blackyouthproject.com/2011/02/ the-rubin-stacy-story-a-meditation-on-lynching-in-a-post-racial-america/ 


\section{Journal of Terrorism Research}

\section{Appendix $\mathrm{H}$}

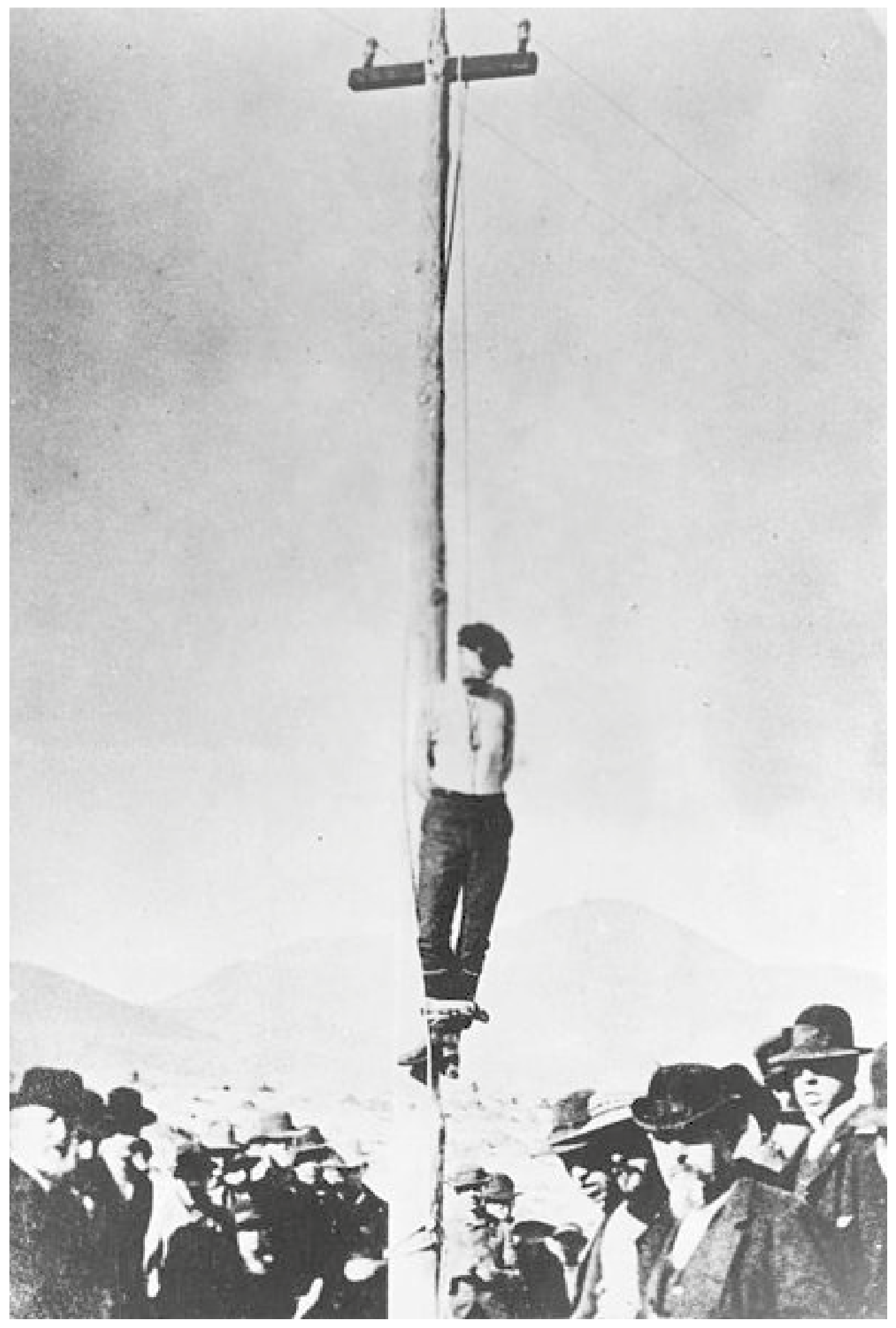

John Heith lynched by a mob in Tombstone, Arizona on February 22, 1884. From the photo collection of Noah Hamilton Rose, sourced from the US Library of Congress. Accessed on March 25, 2014 at: http:// en.wikipedia.org/wiki/File:JohnHeith.jpg 


\section{Journal of Terrorism Research}

\section{Appendix I}

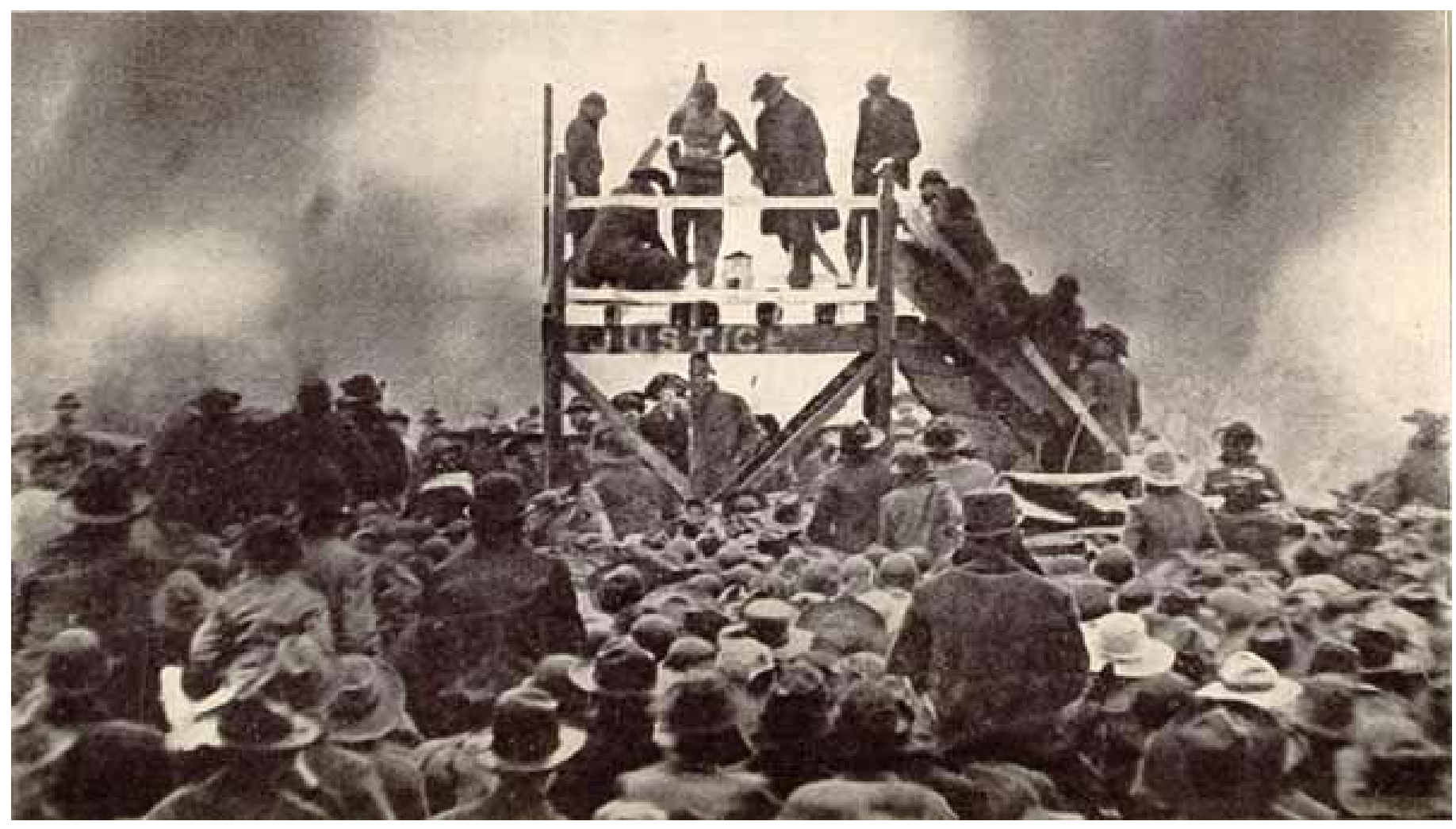

The lynching of Henry Smith in Paris, Texas, 1893. Photographer: Anonymous. Accessed on March 25, 2014 at: http://en.wikipedia.org/wiki/File:Henry-smith-2-1-1893-paris-tx-2.jpg

\section{Appendix J}

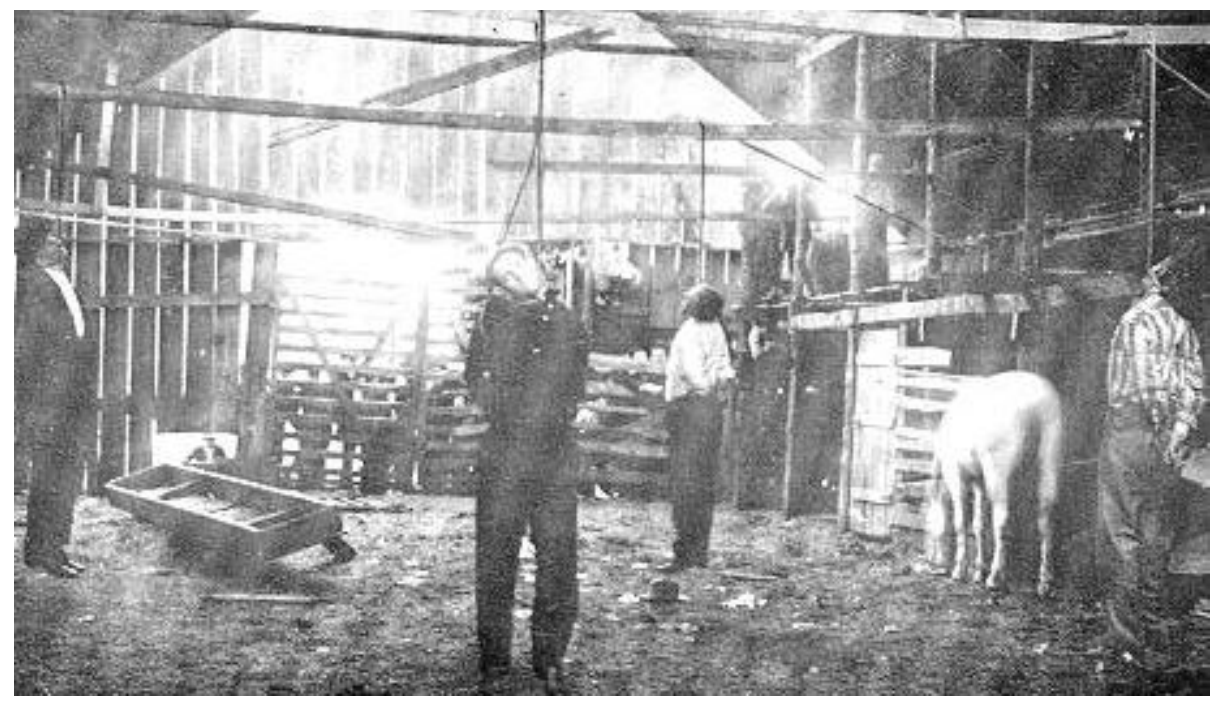

The lynching of 'Killer' Jim Miller and others. Ada, Oklahoma. Published in The Daily Ardmoreite Ardmore, Oklahoma Monday, April 19, 1909. Accessed on March 25, 2014 at: http://en.wikipedia.org/wiki/File:Jim miller hanging.jpg 


\section{Journal of Terrorism Research}

\section{Appendix $K$}

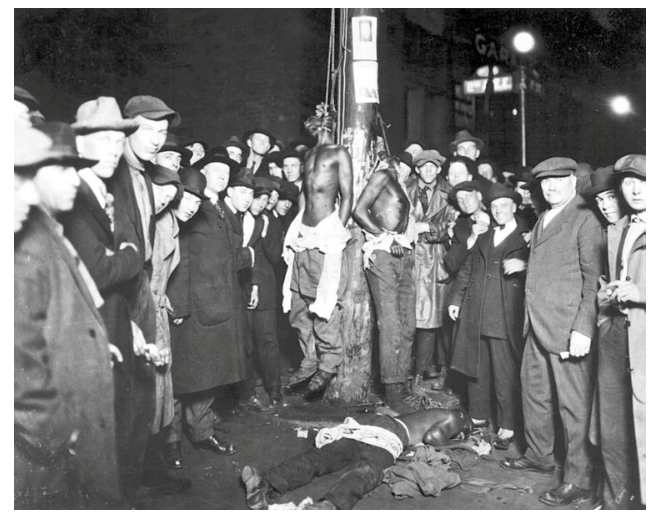

A postcard of the Duluth lynchings, June 15, 1920. Photographer: anonymous. Accessed on March 25, 2014 at: http://en.wikipedia.org/wiki/File:Duluth-lynching-postcard.jpg

Appendix L

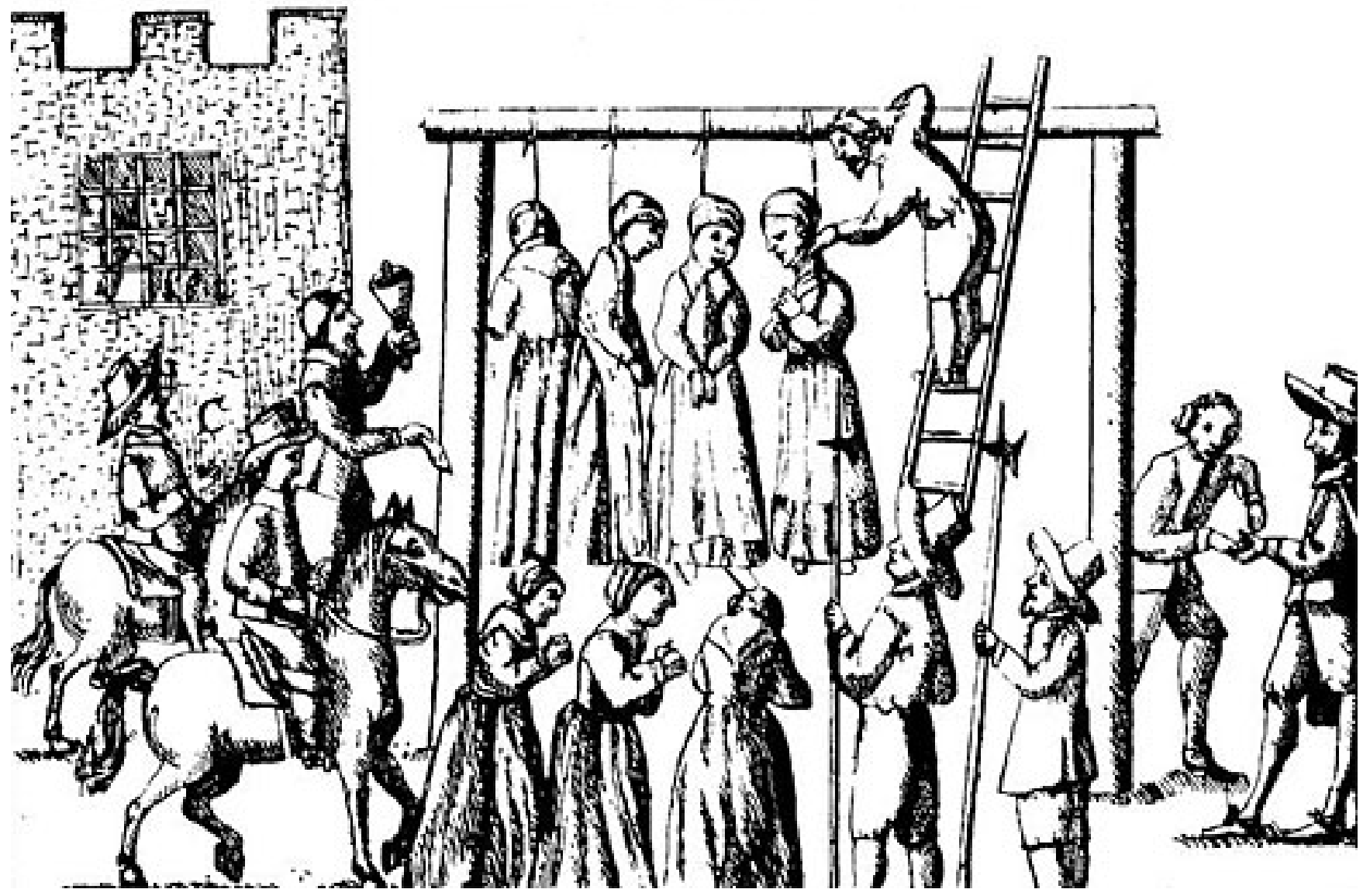

Illustration of witches being hanged, from Ralph Gardiner's England's Grievance Discovered in Relation to the Coal Trade, 1655. Published in A New History of Witchcraft by Brooks and Alexander (2007), page 69. Accessed on March 25, 2014, at: http://en.wikipedia.org/wiki/File:Witches Being Hanged.jpg 


\section{Journal of Terrorism Research}

\section{Bibliography}

Ackermann, S. (2014): 'Marines investigate photos allegedly showing burning bodies in Iraq' in The Guardian (January 15, 2014), accessed on March 23 at: http://www.theguardian.com/world/2014/jan/15/us-marinesphotos-iraq-investigation-burned-bodies

Artaud, A. (1938): The Theatre and its Double. Translated by Victor Corti. Oneworld Classics. Accessed on March 142014 at: http://www.almaclassics.com/excerpts/Theatre Double.pdf

Apel and Smith (2007): Lynching Photographs. Berkeley and Los Angeles: University of California Press, Ltd. Butler, J. (2009): Frames of War. London: Verso Books.

Bolt, N. (2012): The Violent Image: Insurgent Propaganda and the New Revolutionaries. London: Hurst \& Company.

Carr (2011): The Infernal Machines: An Alternative History of Terrorism. London: Hurst \& Company. Chambers, C (2008): Sex, Culture and Justice: The Limits of Choice. USA: Penn. State University Press.

Danchev, A. (2008): 'Bad Apples, Dead Souls' in International Affairs, 84: 6 (2008) 1271 - 1280. Blackwell Publishing Ltd / The Royal Institute of International Affairs.

Danner, M. (2004): 'Abu Ghraib: The Hidden Story' in The New York Review of Books. October 7, 2004. Accessed on March 14, 2014 at: http://www.nybooks.com/articles/archives/2004/oct/07/abu-ghraib-thehidden-story/

Dubuffet, J. (1967): Prospectus et tous écrits suivants, Vol. II. Paris: Gallimard

Douglas, M. (1966): Purity and Danger: An Analysis of Concept of Pollution and Taboo, London: Routledge and Kegan Paul.

Dworkin, A (1981): Pornography: Men Possessing Women. USA: The Women's Press

Fraser, Anotonia (2002): The Gunpowder Plot. London: Pheonix.

Gentry and Sjoberg (2007): Mothers, Monsters, Whores: Women's Violence in Global Politics. London and New York: Zed Books.

Haynes, Alan (2005) (c.1994): The Gunpowder Plot: Faith in Rebellion. Hayes and Sutton.

Hersh, S. M. (2004): 'Annals of Security: Torture at Abu Ghraib' in The New Yorker. (May 10, 2004). Accessed on March 14 at: http://www.newyorker.com/archive/2004/05/10/040510fa fact?currentPage=all

Hill, Frances. (2000): The Salem Witch Trials Reader. Cambridge, MA: Da Capo Press

Jabri, Vivienne, (1996): Discourses on Violence: Conflict Analysis Reconsidered. Manchester: Manchester University Press.

Juergensmeyer, M. (2000) Terror in the Mind of God: The Global Rise of Religious Violence, Berkeley and Los Angeles: University of California Press (paperback)

Livingston, S. (1994): The Terrorism Spectacle. Boulder, Colorado: Westview Press.

MacKinnon, C (1989): Towards a Feminist Theory of the State, Harvard University Press, USA.

MacKinnon, C (2007): Are Women Human? And Other International Dialogues. Cambridge, Massachusetts: The Belknap Press of Harvard University Press.

Margolick, D. (2001): Strange Fruit: Biography of a Song. USA: Harper Collins 


\section{Journal of Terrorism Research}

Maxwell-Stuart, P. G. (2011): Witch beliefs and witch trials in the Middle Ages: documents and readings. London; New York: Continuum

Maxwell-Stuart, P. G. (2003): Witch-hunters: professional prickers, unwitchers and witch finders of the Renaissance. Stroud : Tempus

Maxwell-Stuart, P. G. (2005).An Abundance of Witches: the Great Scottish Witchhunt. Stroud, Gloucestershire : Tempus

Mitchell, W. J. T. (2011): Cloning Terror: The War of Images, 9/11 to the Present. Chicago and London: The University of Chicago Press.

Moeller, S. D (1989): Shooting War. New York: Basic Books Inc.

Phillips, J (2005): The Marquis De Sade: A Very Short Introduction, Oxford University Press

RT.com (Staff Writers) (2014): 'Abu Ghraib 2.0? Horrifying images of US Marines burning Iraqis prompt military investigation', on RT.com, January 15 2014. Accessed on March 142014 at: http://rt.com/usa/photosus-burning-iraqis-653/

Shapiro, D. (2003): “The Tortured, Not the Torturers, Are Ashamed," Social Research 70, no. 4 (Winter 2003). Sjoberg, L. (2007): 'Agency, Militarized Femininity, and Enemy Others', International Feminist Journal of Politics, vol. 9, no. 1.

Sharpe, J. A. (2005): Remember, Remember: A Cultural History of Guy Fawkes Day. Harvard University Press. Sontag (2003): Regarding the Pain of Others. London: Penguin Books.

Todorov, Tzvetan (2009): Torture and the War on Terror, Seagull Books, USA.

Williams, L. (2004) "Skin Flicks on the Racial Border" in Porn Studies, Ed. Linda Williams. USA: Duke University Press.

\section{Appendix References:}

(A)

US Military Personnel (2003) “Hooded Man.” Accessed on 17 / 07 / 13 at: http://en.wikipedia.org/wiki/ File:AbuGhraibAbuse-standing-on-box.jpg

(B)

US Military Personnel (2003) "Soldier with Abu Ghraib prisoner on leash"

Accessed on 17 / 07 / 13 at: http://en.wikipedia.org/wiki/File:Abu-ghraib-leash.jpg

(C)

US Military Personnel (2003) "Pyramid of Bodies." Accessed on 17 / 07 / 13 at: http://www.newyorker.com/ archive/2004/05/03/slideshow 040503\#slide=2

(D)

The lynching of Jesse Washington in progress, by Fred Gildersleeve, May 15, 1916. Published by the NAACP after their investigation of the lynching in The Crisis Vol. 12, supplement to No. 3. Accessed on March 25, 2014 at: http://www.npr.org/templates/story/story.php?storyId=5401868

(E), (F) and (G) 


\section{Journal of Terrorism Research}

The lynching of Rubin Stacy, July 19, 1935, Fort Lauderdale, Florida. Published in Strange Fruit: Biography of a Song by D. Margolick, 2001. Accessed on March 25, 2014 at: http://www.blackyouthproject.com/2011/02/ the-rubin-stacy-story-a-meditation-on-lynching-in-a-post-racial-america/

(H)

John Heith lynched by a mob in Tombstone, Arizona on February 22, 1884. From the photo collection of Noah Hamilton Rose, sourced from the US Library of Congress. Accessed on March 25, 2014 at: http:// en.wikipedia.org/wiki/File:JohnHeith.jpg

(I)

The lynching of Henry Smith in Paris, Texas, 1893. Photographer: Anonymous. Accessed on March 25, 2014 at: http://en.wikipedia.org/wiki/File:Henry-smith-2-1-1893-paris-tx-2.jpg

(J)

The lynching of 'Killer' Jim Miller and others. Ada, Oklahoma. Published in The Daily Ardmoreite Ardmore, Oklahoma Monday, April 19, 1909. Accessed on March 25, 2014 at: http://en.wikipedia.org/wiki/File:Jim miller hanging.jpg

(K)

A postcard of the Duluth lynchings, June 15, 1920. Photographer: anonymous. Accessed on March 25, 2014 at: http://en.wikipedia.org/wiki/File:Duluth-lynching-postcard.jpg

(L)

Illustration of witches being hanged, from Ralph Gardiner's England's Grievance Discovered in Relation to the Coal Trade, 1655. Published in A New History of Witchcraft by Brooks and Alexander (2007), page 69. Accessed on March 25, 2014, at: http://en.wikipedia.org/wiki/File:Witches Being_Hanged.jpg 